Silvia Caporale-Bizzini*

\title{
Narratives of Space in the Writing of Five Contemporary Canadian Women Writers of Italian Origin
}

DOI 10.1515/anglia-2016-0004

\begin{abstract}
The purpose of this essay is to analyze the English writing of five Canadian authors of Italian origin - Darlene Madott, Maria Ardizzi, Licia Canton, Rosanna Battigelli and Dorina Michelutti - in terms of how they represent personal and inner spaces as a meaningful focal point for interpreting and reflecting on the dislocated subject's quest for identity. I will show how they use the idea of compensatory spaces as a literary strategy to portray personal, private or inner spaces to articulate their characters' processes of accepting or resisting cultural hybridity and multiplicity. The works of fiction I consider here embody the shifting perception of inner or personal spaces in the characters' lives, and how this defines their spatial relationships with the new country in different terms and at different stages of the migrant's process of accepting his or her new country. My reading is based on Homi Bhabha's notions of third space and cultural translation and Michel Foucault's concept of heterotopic spaces; I define these as compensatory spaces, an idea also rooted in Foucault's view that heterotopies of compensation represent differences that transcend dichotomies and are open to fluidity. In this paper, the idea of third space addresses the process of cultural translation - understood not only as the positive and dialogic creation of a hybridized subject, but also as a narrative of conflicting personal spaces that gives voice to experiences of cultural dislocation.
\end{abstract}

\section{Introduction}

The purpose of this essay is to analyze the English writing of five Canadian authors of Italian origin - Darlene Madott, Maria Ardizzi, Licia Canton, Rosanna Battigelli and Dorina Michelutti - in terms of how they represent personal and inner spaces, as a meaningful focal point for interpreting and reflecting on the dislocated subject's quest for identity. I will show how they use the idea of

*Corresponding author: Silvia Caporale-Bizzini, Universidad de Alicante

E-Mail: caporale@ua.es 
compensatory spaces as a literary strategy to portray personal, private or inner spaces to articulate their characters' processes of accepting or resisting cultural hybridity and multiplicity.

In the past, the issue of spatialization within the cultural analysis and representations of the Italian emigration to Canada has often been addressed with reference to interrogating the politics of identity and the articulation of cultural differences - both in Italy and in Canada (Beneventi 2004; Loriggio 2004; Verdicchio 1997). These works mainly focus on how migrant subjects see themselves in relation to displacement and tend to concentrate on one of two issues: either the complex relation between the history of emigration in Italy and the “Italian-Canadiana" (Loriggio 2004; Verdicchio 1997), or else how migrant communities represent their spatial imaginary and question the "(dual) territorial models of Canada" (Beneventi 2004: 217).

However, one question that has not been addressed so far is how gendered representation of personal compensatory spaces, as a writing strategy, reflects on the issue of ethnicity and dislocation; and also how these representations showcase the way that Ardizzi, Madott, Canton, Battigelli and Michelutti interpret the experience of emigration and the process of cultural translation. Though their works do not represent the canonical literary stream within Italian Canadian literature, my choice is based on the idea that their narratives address and represent the different stages of the spatial experience of displacement within diverse socio-cultural climates on the wake of the massive flow of Italian emigration to Canada after WWII. The works of fiction I consider here embody the shifting perception of inner or personal spaces in the characters' lives and how this defines their spatial relationships with the new country in different terms and at different stages of the migrant's process of accepting his or her new country. In this essay, I will focus on that issue.

My reading is based on Homi Bhabha's notions of third space and cultural translation and Michel Foucault's concept of heterotopic spaces; I define these as compensatory spaces, an idea also rooted in Foucault's view that heterotopies of compensation represent differences that transcend dichotomies and are open to fluidity (1998: 177 and 179). In this paper, the idea of third space addresses the process of cultural translation - understood not only as the positive and dialogic creation of a hybridized subject, but also as a narrative of conflicting personal spaces that gives voice to experiences of cultural dislocation (Ahmed 2003; Sabra 2008; Stock 2010; Anselmi 2011; Christou 2011; Tuzi 2011).

The writers I study here have different life paths. Battigelli, Michelutti and Canton were born in Italy in the early sixties and raised in Canada; Ardizzi emigrated with her husband in 1954; and Madott was born in Canada. All their narratives similarly negotiate the issue of emigration and reinvent or reject new 
spaces of belonging. Ardizzi's protagonist questions the duality of the old country versus the new; the stories of Battigelli and Michelutti embody the tension of accommodating maternal peasant culture in Canadian life. ${ }^{1}$ Madott's story deals with the need of a third generation Italian Canadian to discover her origins and connect with a country that is foreign to her, while Canton's protagonist rejects the concept of homeland as a fixed place.

The chosen authors interpret displacement as a way to articulate their personal explorations of identity in relation to migrancy. Their characters symbolize different layers of representation that respond to distinct cultural and social class assumptions. By translating the different historical realities of their protagonists and their spatial coordinates - the loci of specific anxiety - these writers give meaning to new spaces that can embody various conditions: resistance, acceptance, movement, or estrangement. They describe "a world constituted by the space that brings together 'where you're from', 'where you're at' (Gilroy 1991), and where you're going” (Fortier 2000: 17).

\section{Spaces of Theory}

In the context of geographical and cultural dislocation, people's memories create compensatory spaces that represent the spatial projection of what they feel is missing in their lives (Brah 1996; Fortier 2000; Stock 2010). Such spaces of compensation are not necessarily permanent, but they are subject to a constant transformation and fluidity (Massey [2005] 2010: 9). As a result, they are exemplified by a multiplicity of emplacements that, for better or for worse, represent how "the articulation of gender and ethnicity manifests itself differently in different times and places" (Fortier 2000: 4). These spaces, I argue, represent a constellation of contradictory heterotopic 'emplacements' - a term created by Michel Foucault in his essay "Different Spaces" (1998). ${ }^{2}$ He articulated the notion of a network of spatial relations that define the locus of subjectivity as "a space that is laden with qualities, a space that may also be haunted by fantasy” (1998: 177).

1 Dorina Michelutti (she later changed her name into Dôre Michelut, in her original Friulan language), in her essay "Coming to Terms with the Mother Tongue" (Tessera 6 [1989]: 63-71), explains how her writing becomes a permeable third space of linguistic and identitary creation that allows her to travel through three languages: English, Italian, and Friulan, the language of her peasant family.

2 In Foucault's essay "Different Spaces”, he wrote that such spaces represent where we live, and in which "the erosion of our life, our time, and our history takes place" (1998: 177). 
In my analysis, this concept is associated with the positions that subjects may inhabit between ontological spaces (Cresswell and Merriman 2011; Anthias 1998) at different moments in their lives. I argue that compensatory spaces are not unquestionably "open to cultural translation" (Bhabha [1994] 2010: 233); at the same time, although limited by inequalities and exclusions, the migrant subject is not inescapably bound by his or her traumatic experiences of emigration (Verdicchio 2007). Unlike Bhabha and Verdicchio, I contend that individuals retain the agency, at least partially, to transform these spaces either into a liberating experience, or into a self-inflicted confinement.

Bhabha's notion of third space, and the concept of hybridity, have been widely applied and developed by many scholars (Ikas and Wagner 2009; Berry 2007; Ahmed 1999). Bhabha explains hybridity as the third space that enables other positions to emerge: "The process of cultural hybridity gives rise to [...] a new area of negotiation of meaning and representation" (Bhabha 1990: 211). He notes the similarity between the process of translating from one language into another and from one cultural code into another: "Designations of cultural difference interpellate forms of identity [that are] open to cultural translation" (in Rutherford 1990: 233).

Bhabha is not alone in defining the concept of a new space that embodies the reinterpreting of personal subjectivity, when it comes into closer contact with a different culture. Theorists such as Gayatri Spivak (1990), Edward Soja ([1996] 2010) and Doreen Massey ([2005] 2010) believe that identitary locations contain a fluid and shifting understanding of subjectivity - one that relies not solely on cultural difference, but also on cultural translation. In this paper, my perception of the idea goes beyond the simple linguistic process of moving between languages and embraces the multiple comprehension of cultural, social and spatial codes in order to define specific "diaspora space[s]" (Brah 1996: 11).

In his essay "The Self in Translation" (2007), Pasquale Verdicchio contemplates the subject in the light of Bhabha's 'anxiety of translation'. However, Verdicchio's interpretation centres on a more painful perception of the origin of the creative impulse, in the displaced person's life experience in literary and theoretical terms. He sees the act of translating as "carrying something from one place to another [...] translation is, in essence, movement” (2007: 224). He further notes the power of translation to fill the psychic "gap opened up by emigration" (2007: 225) and equates this with the trauma of loss, grief, longing and homesickness: "Emigration replaces the trauma with another that is called immigration" (2007: 226). In fact, Verdicchio defines the creative drive as the moment when that trauma is verbalized: "Ethnic writing is the expression of trauma" (2007: 227).

In many ways, Verdicchio's view questions the affirmative vision of Bhabha's interpretation of third space: the creative impulse originates not in a positive 
emplacement, but in the consciousness of a void that needs to be filled with words. The immigrant finds herself in a nowhere land where she must learn to cope with a new life and to negotiate new languages, cultural codes, and identities.

Verdicchio's vision of the origin of creative emplacements is voiced partially by poet Mary Di Michele. In "Stranger in You: The Poetics of Migration and Translation" (2007), Di Michele describes how, after moving to Canada at the age of six, she exchanged her former games in the piazza for a seat in the library (2007: 29). The space of the library symbolized for her the process of cultural translation and compensated her for the loss of her home and culture. It represented her entrance into the new culture and the process of existential translation that she started to carry out. Her native Italian language was displaced by English; and little by little, all of her life shifted from one cultural code to the other.

For Di Michele, the anxiety of cultural translation, and of grief for the loss of her cultural origins, was transformed into a space of creative power. "If estrangement is the worst, it is also perhaps the creatively richer response for the writer", she observes (2007: 32). Still, if the act of translating is a way of travelling through cultures (as Darlene Madott's narrative demonstrates), it does not always offer the possibility of reaching a final destination. For example, the works of Ardizzi, Battigelli, and Michelutti give voice to the alienation of displaced peasant characters - symbolized by the rejection of cultural translation and their forging of complicated compensatory personal spaces.

\section{Memory Spaces}

Di Michele's final step into the new culture came when she translated her reminiscences of childhood - suggesting that remembrance ${ }^{3}$ and memories can represent a compensatory space of survival for dislocated people. But what role do memories actually play in the daily redefinition of life experiences in a new land? In the case of displaced subjects, remembrance is most often used as a way of holding onto (or at least not entirely losing) the vital parameters of culture and identity.

3 The term "remembrance" originates in Hannah Arendt's reflections on the need not to forget cultural origins and the past in order to be able to construct a future life in both the private and public realms. 
The primal search for the absent home is powerfully expressed in the opening of Darlene Madott's “On Leave Taking and Monuments” (2007). In this short story, Madott tells how Warren Giovannini travels from Canada back to Italy, driven by curiosity about why his family decided to emigrate five generations ago. The narrator is Warren's partner and, as she explains:

No one leaves country, home, all he has loved, unless driven by a powerful necessity. In the case of my people, it was poverty that compelled my maternal grandparents from Sicily, paternal grandparents from Calabria. But why three Giovannini brothers left Lucca with their father - Lucca, a rich town in the fertile region of Tuscany - surely that could not have been poverty? (Madott 2007: 189)

Madott's story uses the Tuscan landscape and the narrow streets of Lucca to describe Warren Giovannini's personal journey through time and space. She reconstructs the pursuit of family history from personal narratives intertwined with public documents, legal papers, and literary quotes from old books. For instance, she describes the departure of Warren's great-grandfather:

Enrico left, it is suggested, in a period of unrest and warfare, specifically during the conscription of the Garibaldi army in 1860. Left with three sons. Left six sons behind. From what I know of my Giovannini - honourable, loyal man that he is, who takes care of those he loves - Enrico Giovannini would not have left without putting his house in order. (Madott 2007: 193)

Names from Tuscan tradition and history are mixed with references to contemporary Lucca and with the story of the Giovannini family's migration - first to St. Lawrence, Newfoundland and then to Toronto. The narrative travels back and forth in history and between the two countries. It tells of Lucca and St. Lawrence, of Italian bureaucracy, and of the small flat the couple rents on the outskirts of Lucca, imbued with the aromas of traditional cooking.

In this way, Madott clearly defines the network of relationships that delineate the public and private dimensions of identities (as well as the present and historical dimensions). Our selves comprise many elements: history, culture, food, personal circumstances, unanswered questions, opportunities that were never realized. Knowledge of cultural heritage is important not only to define a position in discourses on identity, but also to make people aware of the constellation of feelings and affections that link them to places. As scholar Yi-Fu-Tuan commented, “'Home' is a meaningless word, apart from 'journey' and 'foreign country" (1974: 102). Displaced people forge, in their minds and hearts, an idea of the home they have lost - even though it may barely exist, except as a memory.

In Madott's story, the need to understand the past becomes a narrative that moves back and forth between the present and the past, legend and reality, 
imagined stories and old buildings. The narrative focuses on Warren's need to know where his family came from and why the emigration that shaped his life took place. As Madott wrote: "What is out of focus is the motivation of the Giovannini who left Italy" (2007: 193). But once the family arrives in Canada, the link with history is not lost: "The two Giovannini brothers, Gregory and Celestine, became the first merchants of St. Lawrence; Gregory was my Warren Giovannini's grandfather" (Madott 2007: 191). This story represents a successful tale of adaptation to a new land: the newcomers made themselves at home. "And they built houses. Gregory Giovannini built a house of four-storeys" (Madott 2007: 191). We understand that this process of cultural translation was successful: the characters feel that they belong to both worlds.

The quest for memories can compensate for the gap between the culture of the past and the culture of the present. Nowadays, that gap - at least in terms of physical distance - can be easily overcome. As Madott points out, "A flight of hours now separates Canada from Italy. Nothing as those separations, a century ago" (2007: 196). A generation with no memory may now go back to attempt to fill the void left by emigration and to construct a bridge between the house of the past and the house of the present.

However, as C. D. Minni has noted, the issue of memory can be a complex one. ${ }^{4}$ Sometimes, rather than playing a dynamic role in the lives of displaced individuals, memories become a way of living in a past that no longer exists - a past that becomes a heterotopic space that represents not compensation but a vacant limbo, with no escape. The idea of creative compensatory spaces merges into a complicated relationship with identitary emplacements, which intersects with a fixed understanding of the notion of 'belonging' (Fortier 1999). ${ }^{5}$ As Pasquale Verdicchio implies, despite the fact that Italy, the old country, has become "an abstraction" (2007: 15), a migrant subject's perception of self is still tied to its remembrance.

4 C. D. Minni analyzes some of the female characters in Caterina Edward's story "The Last Young Man”, in Frank Paci's Black Madonna, and in his own short story "Margherita”. He explains that these women have not been able to redefine their vital parameters in the new world, and that their obsessive attachment to memory has kept them shut off from the possibility of a new life. "What keeps these characters marginal?" he muses. "I would suggest memory. People are the sum of their experiences. It shapes their character. It colours their viewpoints. The present is seen in the light of the past, and this light can be quite different when it has been transported across an ocean." (Minni 1991: 65).

5 The term "belonging," and its symbolic significance, is borrowed from Anne-Marie Fortier. It "refers to both 'possessions' and appartenance", she writes. "Practices of group identity are about manufacturing cultural and historical belongings that mark our terrains of commonality." These, she asserts, "delineate the politics and social dynamics of 'fitting in"” (1999: 42). 
In such cases, the experience of displacement and settlement is conceptualized as "symbolic spaces of belonging" (Stock 2010: 25) in material and psychological terms (Stock 2010; Ahmed 2003; Brah 1996). As a result, the compensatory space that subjects construct involves a process of negotiation, shaped by social class and gender, between the old sense of self and the Canadian cultural context (Anselmi 2011; Beneventi 2004; Tuzi 1997). The notion of home is reconstructed according to a set of reinterpreted memories that "encompass both relations to the 'homeland' and feelings of being home” (Stock 2010: 24).

In Maria Ardizzi's novel Made in Italy (1982), the identitary cartography is skillfully and touchingly drawn in the complex inner world of Nora Moratti, the main character. She constructs an emotional space in between Italy and Canada that rethinks "the relation between embodied subjectivity, place and belonging" (Ahmed 2003: 10).

Nora's first-person narration of the mental distance between real and inner spaces at first shows her as almost an empty shell: remembrance embodies the link between her past and her present, where "the new world perpetuates and tragically compounds the gender strife in the old" (Tuzi 1997: 101). The compensatory spaces that encompass her are not physical - they exist only in her mind and psyche, as she reflects on the present, or mentally travels back to the past.

Nora emigrated to Toronto with her husband and her young family from a village in Abruzzo after World War II. An independent young woman, she had always felt trapped by her upbringing and by her life in the home village. After emigrating, her life is marked by a constant sense of estrangement both from her Italian background and from her new life in Toronto - where her husband becomes a wealthy man. In spite of the upward mobility of her family, she feels no attachment to money or material possessions. When she thinks of herself, she claims that: "As far as I am concerned, I am Nora. Strange places do not frighten me; important people do not intimidate me [...]. My relationship with the outside world is that of a spectator at a farce that causes no laughter" (Italy: 29).

The narrative takes the form of a flashback, beginning when Nora is an old woman, a widow, with middle-aged Canadianized children. The story opens as she wakes up in her bedroom, viewing all the objects there as insignificant compared with what she truly cherishes - her memories. She sees those as the only major possessions in her life: "My memory is a storehouse into which events have been crammed like belongings into closets I no longer open [...]. [O]f late, the past is my only companion" (Italy: 13-14). A lifetime of hard work has left her comfortably off, but she feels estranged from everything material in her present life. Only by looking into her past can she try to make sense of her present. "I have entered a dimension where time and space are unbounded: whence I came and wither I am going are questions belonging to the past and to the future: my 
quest for answers which I cannot give has ended in grasping onto the present" (Italy: 14).

The material things that her late husband (like many immigrants) filled their house with, as symbols of desirable upward mobility, are meaningless to Nora because they represent, for her, his obsession with making money. This meant long hours away from home, from Nora and the children, and a lack of commitment to their marriage and to family life (Pivato 1985). The insignificance of these material things contrasts with the influence of some old books she found in a chest in her parents' attic, when she was ten years old: "Those books that I had been able to save, I kept hidden in my room and I read them at night" (Italy: 14). The configuration of spaces always plays an important role in characters' unique experiences of the relationship between space and memory (or the memory of spaces).

Nora reinvents emplacements of love where she felt protected (even by her parents' suspicion of books and education); it is through these reinterpreted memories of familiar spaces that she assembles a metaphorical bridge between past and present and reconfigures her imagined homeland as a compensatory space. The attic is converted into a liminal emplacement, recreated by Nora in between spatial and temporal dimensions. From that place she can travel to and from the present, and from her birth house to her current house. Still, the journey gives her no significant relief. "A great deal of time has passed since then. I feel exhausted, as if I carried all the unresolved questions of those who have come before me, and those who will come after" (Italy: 22).

The complexity of Nora's mind is revealed as she tells of the spaces that have contained her life, but at the same time have always been connected to her feeling of estrangement. She does not verbalize her tale - it is only a silent story that she tells to herself. She is not able to communicate with her family or the outside world, and alienation has become a lifelong condition for her (Tuzi 1997: 103; Pivato 2003: 84). Nora resists adaptation and cultural translation, especially after her husband's sudden death in Italy - and then, tragically, the deaths of two of her three children. These events comprise the final and definitive negation of material spaces. Even her maternal village is foreign to her when she goes back there to visit:

In a kind of stupor, I found shreds of myself little by little as I neared my homeland. Nothing was the same. My parents were dead. The abandoned house on the street had been sold by Michele, years before, together with the lands. There wasn't even a house of my own to which to return [...]. My surroundings have remained intact only in my imagination, and I cannot possess them except in my imagination. Do you want to know something? I don't really have a place anymore. I don't belong to any place [...] and I belong to all places. (Italy: 145, 147) 
Nora rejects both Italy and Canada, perceiving them both as equally restrictive; her body and memories become her homeland (McDowell 1999; Westerlund 1999; Luksaite 2010). For her these represent "a psychological space of subjectivity" (Westerlund 1999: 66) that exists in between territories.

After the death of her younger son at the age of thirty, Nora has a stroke. At this point, her paralyzed body - and her still-vivid mind - become the only authentic dwelling of her "discontinuous self" (Tuzi 1997: 101). She muses about "others whom the city hides, a silent crowd not yet ready to die, and nonetheless transformed by misfortunes and by deception. Those who have never prayed, pray; those who have never cursed, swear; they cry or whine, or don't hear; or they dream or lose their sanity. Me, I return to my memories” (Italy: 67). By this point, Nora has assimilated the traumatic changes in her life and her feeling of dislocation, by using her memories as a means of achieving continuity with the past. She rejects any connection both with the new culture and the old; memories act as a compensatory space where she takes refuge - yet in the process, she transforms them into a self-imposed prison.

In a very different short story by Licia Canton, "From the Sixth Floor” (2008), the verbal site of "grief", "trouble" and "disconnection" (Young 2009: 82) is poignantly voiced. The story recounts the inner dialogue of a young woman physically and psychologically abused by her new husband and portrays the anxiety produced by her feelings of being cut off - of "partial eclipse" (Young 2009: 88). Canton interprets the materiality of closed spaces as both projection and container of emotional distress.

Polarities are the backbone of this narrative. The unnamed narrator - the protagonist's present self - is an educated young Canadian woman married to an Italian man. They live in Italy now; and she converses with her former self in order to connect with a past that once represented a life full of expectations. "Where are you now? Were you once me?" she asks of that former self. "Where am I? Whom have you become? Are you really gone? Is there a chance that I will find you again or are you lost forever? Is this the me that I am left with? Is this me the one that I have to live with?” (Canton 2008: 41). In this story, remembering is a forward-looking action that initiates a painful process of redefining personal spaces in a new environment. Remembrance can be considered productive here, because it helps to construct a bridge to a new life that the character must negotiate.

Canton's story questions the notion of home as a safe space where the protagonist is free to develop survival strategies of spatial reinterpretation. The narrator does not look back to her previous Canadian life in order to reinvent an imaginary emotional shelter, as Nora Moratti did. On the contrary, she breaks geographical and physical boundaries to embrace the opportunity of a future 
filled with many possibilities. In this narrative the solution to a traumatic displacement is not the construction of a fixed heterotopic compensatory environment, or the negation of a process of cultural translation - since violence against women speaks a universal language. Instead, the solution is the quest for a new life. Movement between spaces is the element that bridges the gap between a sense of paralysis and a possible future identity. As Doreen Massey observes: "To travel between spaces is to move between collections of trajectories, and to reinvent yourself in the ones to which you relate" ([2005] 2010: 130).

The protagonist's inner struggle takes place in a flat on the sixth floor; we soon discover that this is a significant plot element, since her abusive husband tries to convince her to commit suicide by throwing herself out of the window. According to Bachelard's poetic reading of spaces, the verticality of modern blocks of flats symbolizes their dwellers' lack of roots (1965: 58) - an interpretation that fits our protagonist's daily life. Hers has become isolated, full of anguish. She is alienated from her family and friends, and her existing experience of 'home' questions "idealized images of home as devoid of tension, pain or oppression" (Sabra 2008: 84). The depiction of what she has to endure, day after day, is tragic: "He is beginning to pressure me. It is getting to be too much for me. He begins his tirade of verbal abuse when I am in a confined space, when I am trapped" (Canton 2008: 45).

However, Yi-Fu-Tuan offers a different interpretation of verticality, one that relates it to resistance: "Vertical elements in the landscape evoke a sense of striving, a defiance of gravity” (1974: 28). Both Bachelard's rejection of verticality and $\mathrm{Yi}$-Fu-Tuan's more positive interpretation may allow readers to better understand the protagonist's brave fight against domestic violence and her desire to recover her own life. The inner dialogue between the you of the past and the $I$ of the present; the memories of past times, of her family, and former life and dreams - these contrast with the murky and static present. The dual symbolisms of verticality converge as a powerful force that finally becomes a movement toward a new beginning.

This young woman's personal (compensatory) space achieves motion, which will bring her to a new life and different choices. By the end of the story, she has psychically and physically broken away from her husband and the sixth-floor flat: "I sit on a train pulling out of Termini Station. I don't know where I will go, but I am leaving" (Canton 2008: 47). Canton's interpretation of spaces breaks with the trope of the return story in Italian-Canadian literature as the newly found perception of a dual identity (Pivato 1985; D'Alfonso 1996). Here the symbolic homeland is neither Canada nor Italy, but a space-in-progress represented by the journey that the protagonist starts towards her rebirth. 


\section{Spaces of Belonging}

Compensatory spaces may also represent conflict-filled relationships and/or fear of change of the traditional family structure - which often represents the phantasmal projection of the old country and of a deep-rooted and reassuring sense of self (Iacovetta 2000; Rota 2011). Initially, most peasant immigrant women from Southern Italy perceived Canadian society as threatening because of its emphasis on individualism (Vigilante Mannino 2000). The subaltern social groups that migrated were not "the standard bearer[s] of bourgeois Old World Culture" (Perin and Sturino 1989: 17), and their former cultural references were the village (paese) and the family (famiglia). Their peasant culture was matriarchal and within the private domain, women were considered the transmitters of cultural values (Vigilante Mannino 2000: 21 and 35; Perin and Sturino 1989). From the now-absent paese, the displaced subject must relocate herself in relation to the new society of Canada which she experiences as "difficult cultural terrain" (Beneventi 2004: 222).

The organization of space offers a means for ordering the present existence of displaced people, while providing them with a psychic background - an identifiable concept of reality. The basement of a house, for example, may symbolize many repressed psychological issues: the shadows of unresolved relationships; the difficulty of fully accepting the habits and values of a new land; or, paradoxically, the materialization of a distorted idea of continuity. It may also be viewed in psychic terms as a concealed 'deep' part of the house, where hidden thoughts and repressed feelings emerge. The basement then becomes a locus of psychological weight, where rationality is difficult to retain and (emotional) darkness embraces the individual (Bachelard 1965: 51). Such a locus may turn into a representation of a phantasmal secure past; spatial organization is connected to the existential understanding of the displaced subject.

The organization of space is also connected to a woman's need to answer questions concerning her role in this new world, in a society she may hardly accept. If she misses her old $I$ and cannot discover a new one (she may even actively resist creating one) - then will she keep her perception of herself alive within the spaces of memory? That means her world would be divided into the inside psychic space - which retains her old subjectivity - and the physical outside space, representing menacing forces of identitary disruption. As a result, the basement may represent for her the impassable boundary between the old and familiar perceptions of traditions and country (which possibly exist only in her mind); and the real and present possibility of accepting a more fluid approach to her subjectivity.

Two short stories that I will discuss here feature not only physical spaces but also their purpose: the rituals of preparing traditional food. In both Rosanna 
Battigelli's “Francesca's Way" (1998) and Dorina Michelutti’s "What Can I Offer You?” (1989), basements have a symbolic importance in the self-perception of migrants. As David Howarth reminds us, "physical space is always shaped and mediated by a passage through the subject" (2006: 115). The notion of 'belonging' is intertwined with the use of basements as a survival space - and with an old and reassuring sense of self, based on the comfort of traditional gender relations in peasant culture.

Using Judith Butler's theory of performance and performativity as a starting point, Anne-Marie Fortier sees migrant rituals as a practice of resistance. After the diaspora experience, individuals use certain activities (in this case, the ritualized production of food in a basement) to fight against becoming nomadic and to develop practices of belonging. Fortier defines this process as the de-territorialization and re-territorialization of migrant identities (1999: 42). We can recognize the configuration of this space of compensation as a way of re-territorializing an identity.

This concept is related to the idea of belonging to a specific ethnic group and migrants' needs to feel that they still fit into a society that sees them as outsiders (Fortier 1999: 42). This feeling of belonging is formed through the repetition of rituals aimed at preserving emotional ties to a community by constantly reproducing "social categories and norms of membership" (Fortier 1999: 43). In this context, remembrance is linked to the rituals in order to create "images of duration and continuity" (Fortier 1999: 45). While I agree with Fortier's use of the notion of performativity, I rely on her insights only as a starting point. In my view, in these two short stories belonging and re-territorialization are ways of resisting cultural translation and of moving beyond identitary paralysis.

In "Francesca's Way", the protagonist, Angie, and her mother, Francesca, are making sausages in the basement of the family's suburban house in Toronto. Francesca has kept up this ancient gastronomic tradition from her youth in Italy; and its performance and location set the stage for the portrayal of the tense relationship between mother and daughter. We witness the social and generational clash in an immigrant family where the daughter does not accept the continuance of traditional gender roles. Francesca, who considers herself a guardian of traditional values and hierarchical family relations, sees Angie's decision to divorce her husband as an attack on the only social structure that she accepts even though by this point, that structure merely exists in her memory: the Italy she used to know has disappeared. Her daughter's frustrated internal monologue makes this very clear: "Stubborn woman, Angie thought. Stubborn, stubborn woman. And narrow-minded. Stuck in the old ways” (Battigelli 1998: 173).

The representation of personal spaces as a projection of different processes of cultural translation embodies the clash between women's roles both within the 
traditional ethnic group and in its relationship to contemporary Canadian society (Tuzi 2011: 38). Furthermore, these representations also question traditional male gender roles and authority (Tuzi 2011: 42); in this sense, the basement as a place for making food and getting together with friends also symbolizes nostalgia for the old world in Dorina Michelutti's “What Can I Offer You?" Pieri, the protagonist, lives in Canada now; he has a good job, an Italian wife and a new baby, and his life seems to be under control. The basement is his place, where he makes cheeses and sausages from his homeland; it is also where he gathers with his friends and dares to talk about the differences between his birth culture and the new one - differences that he experiences as shadows in his current life. In spite of his achievements, he feels a deep nostalgia for his old country and cannot help feeling some distrust for the culture and habits of Canada. His friend Jaku tries to talk sense into him: "Pieri, we emigrated so our children would never know hunger. You can't expect everything else to remain the same” (Michelutti 1989: 45), he warns.

Despite his friend's advice, Pieri cannot fully accept his present situation. His feelings of displacement and partial rejection of Canadian cultural values can also be understood as a threat to his sense of male primacy within the family unit. They originate "in an unfamiliar socioeconomic context [that has] led to subtle shifts in the roles played by members of the family" (Tuzi 1997: 12). For Pieri, the past holds the notion of order and sameness within a patriarchal family structure, based on the traditional idea of masculinity. As a result, his rejection of the present is based on the social and discursive shift that brings with it the possibility of new definitions of gender - ones that question the security of his traditional values.

In both these stories, in the cases of Francesca and Pieri, the attachment to old rituals - ones that impede their potential integration into identities in the new country - function as negation of a new (and possibly more fulfilling) life. The characters' insistence on constructing performative spaces of belonging, as a way of retaining an old identitary self, can be interpreted as their attempts to repair "interrupted lives [...] where events have disrupted expectations of continuity" (Christou 2011: 250). Still, these two characters' attachment to the past is so strong that it eventually stops them from moving on in their current lives. As Massey explains, "the imagination of going home [...] so frequently means going 'back' in both space and time. Back to the old familiar things, to the way things used to be [...]. But places change; they go on without you" ([2005] 2010: 124). 


\section{Conclusion}

Two recurring aspects of these works I have analyzed are the central presence of personal compensatory spaces as meeting points between the past and the present as well as a different approach to cultural translation. As a literary strategy, the representation of these spaces symbolizes the diversity of the characters' experiences of displacement and of "Canadian-ness" (Tuzi 1996: 85). Their understanding of personal spaces is informed by gender, social class, and their historical locatedness. Battigelli's and Michelutti's characters of Francesca and Pieri, and Ardizzi's Nora, all resist (in their different ways) the idea of a successful dynamic of cultural translation. Spaces are represented as self-contained - even self-accepted - prisons, which tie the characters' perceptions of who they are to a mythical, fossilized, unreal past. They represent an escape from a current reality that the characters are unwilling or unable to accept, an escape that they unconsciously use to try to compensate for the identitary void created by displacement.

Francesca and Pieri recreate spaces that symbolize the old order of their peasant culture. Their resistance to integration sprouts from their fear of becoming 'others' in their own culture as well as in the new one (Anselmi 2011); but that resistance also locks them into an "ethnic ghetto" (Beneventi 2004: 220) and into “an ambiguous position 'between' cultures” (Beneventi 2004: 221). And Nora's decision to accept only her reinterpreted past as psychic homeland exemplifies a "process of re-signification" (Luksaite 2010: 2) of herself as a diasporic subject. She rejects both Italy and Canada and lives imprisoned in the nowhere land of her memories.

Conversely, in Darlene Madott's quest for answers about the history of the Giovannini family, the idea of compensatory spaces is expressed through Madott's new love for the city of Lucca. This process is represented by the journey through history and family origins that forge the displaced migrant's multiple selves through the process of discovering multiple physical dwellings. The self opens up to a new reality, a productive third space whose boundaries are fluid and open to understanding the self in a positive way - the result of a successful process of cultural translation across generations.

And in "On the Sixth Floor", compensatory personal spaces are represented by the protagonist's inner life and strength and by her topography of past times that functions as a bridge to the future. Canton questions the opposition of dwelling and displacement; by locating her protagonist in Italy, she interrogates the notion of belonging in relation to the symbolic space of nationhood. This offers the character the chance to "transform adverse housing environments" (McDowell 1999: 89). The sense of belonging is not unavoidably bound to an unshakable notion of territoriality. Rather, Canton views it as a process, represented by the 
character's physical journey toward freedom and a new life. In this case, 'home' is not the place where the journey originated, but the eventual destination - even though the place she arrives at may turn out to be only transitory. ${ }^{6}$

\section{Works Cited}

Ahmed, Sara. 1999. “'She'll Wake up One of These Days and Find She's Turned into a Nigger': Passing Through Hybridity”. Theory, Culture \& Society 16.2: 16-87.

Ahmed, Sara, Claudia Castañeda, Anne-Marie Fortier and Mimi Sheller (eds.). 2003. Uprooting/ Regroundings: Questions of Home and Migration. Oxford/New York: Berg.

Anselmi, William. 2011. "Reading Displaced Writing”. In: Howard A. Doughty and Marino Tuzi (eds.). Culture and Difference: Essays on Canadian Society. Toronto: Guernica Editions. $15-35$.

Anthias, Floya. 1998. "Rethinking Social Divisions: Some Notes Towards a Theoretical Framework”. The Sociological Review 46: 505-535.

Ardizzi, Maria. 1982/1999. Made in Italy. Toronto: Guernica Editions.

Arendt, Hannah. 2006. Between Past and Future: Eight Exercises in Political Thought. New York: Penguin.

Bachelard, Gaston. 1965. La poética del espacio. Fondo de Cultura Económica: México.

Battigelli, Rosanna. 1998. "Francesca's Ways”. In: Joseph Pivato (ed.). The Anthology of ItalianCanadian Writing. Toronto: Guernica Editions. 171-178.

Beneventi, Domenic. 2004. "Ethnic Heterotopias: The Construction of 'Place' in Italian-Canadian Writing”. In: Lianne Moyes, Licia Canton and Domenic Beneventi (eds.). Adjacencies: Minority Writing in Canada. Toronto: Guernica Editions. 216-234.

Berry, Ashok. 2007. Cultural Translation and Postcolonial Poetry. Basingstoke: Palgrave Macmillan.

Bhabha, Homi. 1990. “Interview with Homi Bhabha”. In: Jonathan Rutherford (ed.). Identity: Community, Culture and Difference. London: Lawrence \& Wishart. 207-221.

Bhabha, Homi. 1994/2010. The Location of Culture. London/New York: Routledge.

Brah, Avtar. 1996. Cartographies of Diaspora: Contesting Identities. London/New York: Routledge.

Canton, Licia. 2008. "From the Sixth Floor”. In: Licia Canton. Almond Wine and Fertility. Montreal: Longbridge. 41-47.

Christou, Anastasia. 2011. "Narrating Lives in (E)Motion: Embodiment, Belongingness and Displacement in Diasporic Spaces of Home and Return". Emotion, Space and Society 4.4: 249-257.

Cresswell, Tim and Peter Merriman (eds.). 2011. Geographies of Mobilities: Practices, Spaces, Subjects. London: Ashgate.

D’Alfonso, Antonio. 1996. In Italics: In Defence of Ethnicity. Toronto: Guernica.

6 This work was supported by a grant from the Spanish Ministry of Science and Innovation between 2010 and 2014 (FFI2010-20989FILO). A previous version of part of sections three and four of this paper was presented in July 2014 at 13th International Conference on the Short Story in English (University of Vienna). 
Di Michele, Mary. 2007. “Stranger in You: The Poetics of Migration and Translation”. In: Delia De Santis, Venera Fazio and Anna Foschi Ciampolini (eds.). Strange Peregrinations: Italian Canadian Literary Landscapes. Toronto: The Frank Iacobucci Centre for Italian Canadian Studies. 29-38.

Fortier, Anne-Marie. 1999. "Remembering Places and the Performance of Belonging”. Theory, Culture \& Society 16.2: 16-41.

Fortier, Anne-Marie. 2000. Migrant Belongings: Memory, Space, Identity. Oxford/New York: Berg. Foucault, Michel. 1998. “Different Spaces”. In: Michel Foucault. Essential Works of Michel Foucault 1954-1984. Volume 2: Aesthetics, Method, and Epistemology. Ed. James D. Faubion. New York: New York Press. 175-185.

Gilroy, Paul. 1991. “It Aint't Where You're From, It's Where You're At: The Dialectics of Diasporic Identification". Third Text 13: 3-16.

Howarth, David. 2006. “Space, Subjectivity, and Politics”. Alternatives 31: 105-134.

lacovetta, Franca. 2000. "From Contadina to Worker: Southern Italian Immigrant Working Women in Toronto 1947-1962". In: Laurel Sefton MacDowell and lan Walter Radforth (eds.). Canadian Working Class History. Toronto: Canadian Scholars' Press. 620-640.

Ikas, Karin and Gerhard Wagner (eds.). 2009. Communicating in the Third Space. London/New York: Routledge.

Loriggio, Francesco. 2004. "Italian Migration Outside Europe: Cultural, Historical and Literary Issues”. Neohelicon XXXI: 19-42.

Luksaite, Eva. 2010. “Constructing the Diasporic Body: Ritual Practices Among the South Asians in Britain”. Asia Eur J 8: 11-24.

Madott, Darlene. 2007. “On Leave Taking and Monuments”. In: Delia De Santis, Venera Fazio and Anna Foschi Ciampolini (eds.). Strange Peregrinations: Italian Canadian Literary Landscapes. Toronto: The Frank lacobucci Centre for Italian Canadian Studies. 189-196.

Massey, Doreen. 2005/2010. For Space. London: Sage.

McDowell, Linda. 1999. Gender, Identity and Place: Understanding Feminist Geographies. Cambridge: Polity Press.

Michelut, Dôre. 1989. “Coming to Terms with the Mother Tongue”. Tessera 6: 63-71.

Michelutti, Dorina. 1989. “What Can I Offer You?” In: C. D. Minni (ed.). Ricordi: Things Remembered. Toronto: Guernica Editions. 41-50.

Minni, C. D. 1991. “The Short Story as an Ethnic Genre”. In: Joseph Pivato (ed.). Contrasts: Comparative Essays on Italian-Canadian Writing. Toronto: Guernica Editions. 61-76.

Perin, Roberto and Frank Sturino (eds.). 1989. Arrangiarsi: The Italian Immigration Experience in Canada. Toronto: Guernica.

Pivato, Joseph. 1985. “The Return Journey in Italian-Canadian Literature”. Canadian Literature 106: 169-176.

Pivato, Joseph. 1986. “Canadian Women Writers of Italian Background”. Italian Canadiana 2: 38-49.

Pivato, Joseph. 2003. Echo: Essays on Other Literatures. Toronto: Guernica Editions.

Raggatt, Peter. 2006. "Multiplicity and Conflict in the Dialogical Self: A Life-Narration Approach". In: Dan McAdams, Dan Ruthellen Josselon and Amia Liebich (eds.). Identity and Story: Creating Self in Narrative. Washington: American Psychological Association. 15-35.

Rota, Emanuela. 2011. "Unwilling Multiculturalism: Italian Immigrant Women and the Americanization Movement”. In: Graziella Parati and Anthony Julian Tamburri (eds.). The Cultures of Italian Migration: Diverse Trajectories and Discrete Perspectives. Madison, NJ: Fairleigh Dickinson University Press. 217-232. 
Sabra, Samam. 2008. "Re-Imagining Home and Belonging: Feminism, Nostalgia and Critical Theory”. Resources for Feminist Research 331/2: 79-102.

Soja, Edward W. 1996/2010. Thirdspace: Journeys to Los Angeles and Other Real-and-Imagined Places. Oxford: Blackwell.

Spivak, Gayatri Chakravorty. 1990. "Poststructuralism, Marginality, Postcoloniality and Value". In: Peter Collier and Helga Geyer-Ryan (eds.). Literary Theory Today. Ithaca: Cornell University Press. 219-244.

Stock, Femke. 2010. “Home and Memory”. In: Kim Knott and Seán McLoughlin (eds.). Diaspora: Concepts, Intersections, Identities. London/New York: Zed Books. 24-28.

Tuzi, Marino. 1996. "Theorizing Canadian Minority Texts: Cultural Specificity, Agency, and Representation". Canadian Ethnic Studies 28.3: 85-94.

Tuzi, Marino. 1997. The Power of Allegiances: Identity, Culture and Representational Strategies. Toronto: Guernica Editions.

Tuzi, Marino. 2011. "Gender and Its Representation in Canadian Minority Literature”. In: Howard A. Doughty and Marino Tuzi (eds.). Culture and Difference: Essays on Canadian Society. Toronto: Guernica Editions. 36-71.

Verdicchio, Pasquale. 1997. Bound by Distance: Rethinking Nationalism through the Italian Diaspora. Madison, NJ: Fairleigh Dickinson University Press.

Verdicchio, Pasquale. 2007. “The Self in Translation”. In: Delia De Santis, Venera Fazio and Anna Foschi Ciampolini (eds.). Strange Peregrinations: Italian Canadian Literary Landscapes. Toronto: The Frank lacobucci Centre for Italian Canadian Studies. 223-228.

Vigilante Mannino, Mary Ann. 2000. Revisionary Identities: Strategies of Empowerment in the Writings of Italian American Women. Berne: Peter Lang.

Westerlund-Shands, Kerstine. 1999. Embracing Space: Spatial Metaphors in Feminist Discourse. London: Greenwood Press.

Yi-Fu-Tuan. 1974. Topophilia. New York: Columbia University Press.

Young, Robert J. C. 2009. “The Void of Misgiving”. In: Karin Ikas and Gerhard Wagner (eds.). Communicating in the Third Space. London/New York: Routledge. 81-95. 